\title{
Interactive Multimedia to Enhance Students' Engagement
}

\author{
Heni Rita Susila ${ }^{1}$, Suyitno Muslim ${ }^{2}$, Zulfiati Syahrial $^{3}$ \\ \{henirietta99@gmail.com ${ }^{1}$, suyitnomuslim@unj.ac.id ${ }^{2}$, zulfiatisyahrial@gmail.com³ ${ }^{3}$. \\ Universitas Baturaja, Sumatera Selatan, Indonesia ${ }^{1}$ \\ Universitas Negeri Jakarta, Jakarta, Indonesia ${ }^{2,3}$
}

\begin{abstract}
Multimedia users have become increasingly in recent days, but knowledge of instructional design in the field of learning science is still inadequate. The purpose of this study was to develop and investigate learning models using interactive multimedia. The research and development refer to the Alessi and Trollip models which are carried out through three phases: planning, design, and development. Product validity involved media experts, learning design experts, and subject matter experts. On alpha tests, the average score of 3.80 is in the valid category. Beta tests involved six students. The average score obtained was 3.56 , which was included in the feasibility category and was liked by students. In the field test step, the questionnaire was distributed to determine the level of student involvement. The score obtained was 79.29 included in the involvement category. This learning model proved to increase student involvement even though the improvement indicators studied are still general.
\end{abstract}

Keywords: Engaging Learning, Interactive Learning, Interactive Multimedia, Research and Development.

\section{Introduction}

Learning by using technologies such as interactive multimedia has become a trend in recent days. From the discussion of various studies, the application of technology contributes effectively to improve student learning outcomes. Technological applications can be applied effectively to help improve students learning [1]. A study in Taiwan stated that multimedia presentation in the form of e-textbook can enhance students learning outcome [2] or digital game-based learning exhibited higher achievement in learning outcomes [3]. Research conducted in Yogyakarta States University showed the students got higher achievement scores compares with students with non-multimedia learning [4]. Multimedia is a woven combination of digitally manipulated text, photographs, graphic art, sound, animation, and video elements. When you allow an end user also known as the viewer of a multimedia project to control what and when to convey the elements, it is called interactive multimedia [5]. Learning can use interactive multimedia as a technology application. Interactive multimedia learning needed by teachers in schools to support teachers' success in implementing the learning process in the classroom more optimally [6]. Users can choose the menu according to what they want for the next process through the controller as multimedia interactivity. The advantage of multimedia is to attract the senses and attract interest because it is a combination of views, sounds and movement [7]. Multimedia according to art or educational system is the use of multiple media used for expression or communication and the existence of a dynamic user-state or contentaltering capability [8]. The terms of expressions and communication explicitly indicate the 
existence of an interactive process, communication here is assumed as a process of interaction between the two parties who exchange information, mutually evolving and changing. One of the advantages of using interactive multimedia is it shifts the user's role from observer to participant. Furthermore, the multimedia design will reinforce and strengthen the traditional instructional communication process and foster a number of innovative methods to communicate knowledge to the learners [9].

There were a lot of studies that explored the effectiveness of interactive multimedia, however, but no one has explored how its role in growing students engaged in learning. Then in this research, it would be discussed how far interactive multimedia can increase students' engagement in learning. Engagement is a growth-producing activity through which an individual allocates attention in active response to the environment [10]. Researchers have recently used the term engagement to refer to the extent to which students identify with and value schooling outcomes, and participate in academic and non-academic school activities [11]. Shernoff more emphasized that engagement is the heightened, simultaneous experience of concentration, interest and enjoyment in the task at hand [12]. It was identified three dimensions to build students engagement. They are cognitive engagement, emotional engagement and behavioural engagement [13].

The major problems found by the researcher is that students' score has not met the minimum criterion specified. Besides, the university located which is far from urban areas makes the whole elements of the university have to struggle hard to compete with other universities. Preliminary studies conducted by interview, survey method, and the main obstacles faced by lecturers in the learning process is the lack of facilities for lecturers to provide varied learning model. The results of the survey on students showed that they got difficulties of the signal to access online material such as on the internet and the condition of the class which is large class does not support them in the learning process in the classroom. Researchers tried to find a solution by creating a model for learning which can increase students' enthusiasm in the learning process. Researchers also developed instruments to measure student engagement in applying this model.

Developing instructional multimedia needs some different theories of learning that underline all instruction and learning environment. Interactive multimedia must be built on sound human factors to be effective. The human factor is the study of the interaction of people with technologies. The environment is a stimulus that can affect or change the capacity to respond. Learning multimedia products will act as a stimulus expected will rise learning outcomes. One behavioristic figure, Thorndike in introduces three laws [14]: First, the law of effect states that, if the stimulus gives a satisfying response it will strengthening the connection of stimulus and response and contrary if the response is annoying, so it weakens. Second, the law of exercise state that the repetition will increase the good response of students. Third, the law of readiness describes the preparation of conditions to make students ready to get a satisfying response. The law of exercise will be implemented by multimedia designing products, that allow users to repeat their own material, this will adjust students' abilities. Pleasant feedback will appear when students can answer questions correctly so that students feel happy. Feedback can be in the form of scores, pleasant pictures or pleasant praise. This feedback is the application of the law of effect. In applying the law of educator readiness, it still plays a role in generating a sense of comfort in the students. The characteristic of Albert Bandura's social learning theory is that one can learn by observing how the model acts and imagines as if the observer experiences what the model experiences. Interactive multimedia can be a model for users. Bandura describes learning as a model-based approach. If the behaviour (skill, knowledge) observed is considered to be worthy, it will be 
adopted. Here Bandura describes the necessary cognitive aspect of one's development. Reasoning and decisions are part of learning. They happen based on the existing trained models [15].

The objective of doing this research is to know how is the valid procedure in developing interactive multimedia. It would be applied during one semester for Instructional Strategy subject 5th semester at the educational technology department of Baturaja University, Indonesia. The next objective is how is students' engagement in using that media. However many researchers developed learning media but how is its effect on students engagement rarely discussed.

\section{Research Method}

The procedure in this research and development followed Stephen M. Alessi and Stanley R. Trollip model. They divided the developing process into three phases, that is planning, design, and development [16]. Formative evaluation step conducted by (1) doing alpha testing, it is validating the product by media expert, learning design expert and subject matter expert. Alpha testing is used to determine the validity of this learning model. The data collection in alpha testing by spreading questionnaire and interview. The interview results, comments and suggestions from the validators determine whether will revise the instructional model or not. The product is valid if the validator suggested it tested feasible; (2) Conducting beta testing, which is to test the product on small group students who fill the criterion of moderate, low and high ability. In this study, six students were chosen to represent each criterion. While in the field test, a larger group of about 20 students tested the product. It calculated using the gain score to know the improvement of learning outcomes. In the field test, the researchers distributed questionnaires to find out students engagements during the application of this learning model. The method used to gain information about students engagement is qualitative descriptive. Data collection techniques used in this study are questionnaire and interview. Questionnaire to determine the needs analysis before developing the instructional model and find out students' engagement. To find out students' engagement in this study spread questionnaire consisting of behavioural, cognitive and emotional aspects. The content of the questionnaire includes indicators that indicate students' engagement in the learning process. Interviews to get information about the weaknesses and advantages of this learning model.

\section{Results and Discussions}

Interactive multimedia is developed based on three phases, namely planning, design, and development. There are many steps in each phase. However, this research will only use the necessary phases as illustrated in Figure 1. showed in Fig. 1 


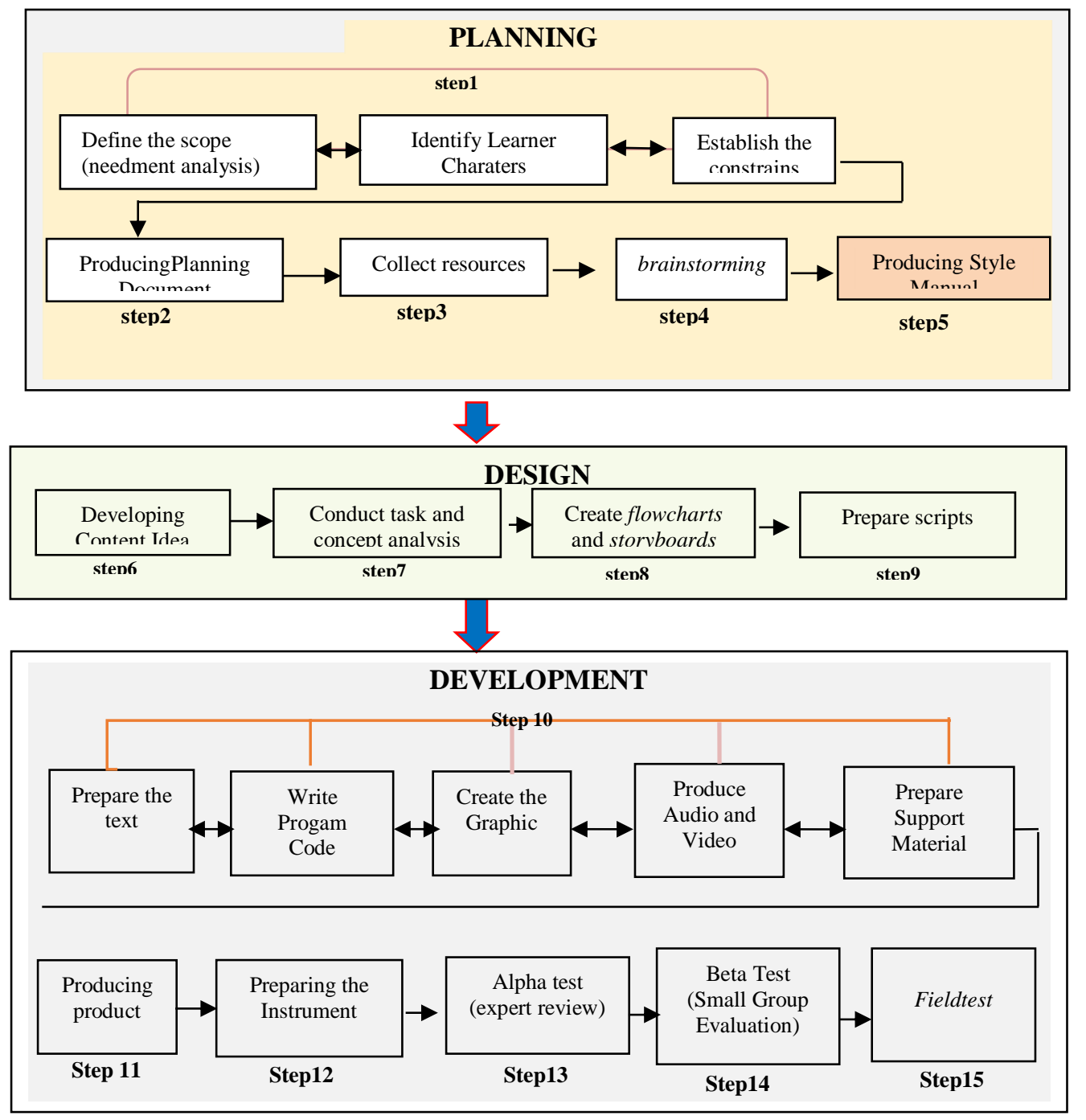

Fig. 1. Fase in developing interactive multimedia learning.

At the planning phase, the researcher started from conducting a needs analysis by interviewing lecturers and students. Then it obtained a result that lecturers often found difficulties in delivering the material and lack of time in preparing varied media for learning. In the instructional process lecturer used to use visual media, audio-visual, picture, textbook and Powerpoint. The result from the interview with students stated that they liked learning to use interactive multimedia, but not all material was in the form of interactive multimedia. Another result from survey and interview showed that student had a bad habit of reading. Besides that, researchers also conducted an analysis of the use of media and learning strategies and infrastructure facilities in learning. The Educational Technology department has three computer labs, each consisting of about 30 computer units. From the identification of 
students' characters, students who took part in instructional strategy courses had different school backgrounds from senior high school, religion high school or vocational high school so that the skills in operating computers also varied, but generally assumed they have been able to operate a computer. Baturaja is a small town in a district in South Sumatra Indonesia. So that students' ability in operating computers also needs to be considered. During applying these planning steps, researchers also always do brainstorming with peers. The final result of the planning phase is a draft manual style on taught materials in instructional strategy courses for one semester.

In the design phase, researchers designed the flowcharts and storyboards of interactive multimedia products. Then designed the flow of delivering material using interactive multimedia, the link between the material presented through interactive multimedia must be clearly structured. In developing, phase researchers produce products, after preparing all the elements needed such as pictures, videos, graphics, material, etc. the result of this product is interactive multimedia which in its operation based on computer and a module which can be used manually in the form of a printed book. Designing the learning process is through faceto-face meetings and independent learning. Some material is presented through the module and for deep understanding students could access it through interactive multimedia everywhere. Quiz and evaluation also spread through instructional multimedia. Instructional multimedia aims to make students easier to repeat their lessons at home without being burdened by internet quota.

First, make and validate instrument products until they are declared suitable for use. After the learning model and all of its components are ready to use than did the formative evaluation. In the alpha testing stage, the completed initial product is validated by media experts, learning design experts and subject matter experts. Researchers carried out the process of validating interactive multimedia products to media expert, learning design expert and subject matter expert. Interactive multimedia is declared valid with an average score of 3.98 as shown in Table 1.

Table 1. Result of Alpha testing

\begin{tabular}{l|c|c}
\hline \multicolumn{1}{c|}{ Expert } & Score & Average Score \\
\hline Material expert & 4,16 & \multirow{2}{*}{3,98} \\
\hline Instructional Design expert & 4,00 & \\
\hline Media expert & 3,80 & \\
\hline
\end{tabular}

After revising alpha testing, the next step was beta testing. Selected six students of the fifth semester who attend Instructional Strategy subject matter who fulfil the criterion of with high, medium and low abilities. The selection of this capability category referred to lecturer recommendation. Researchers gave questionnaires and conducted interviews. The results of interviews with the six students stated that the use of interactive multimedia in learning instructional strategy courses needed to be continued by lecturers. Learning with interactive multimedia is fun and easy to understand. The display on the screen and, simulation and animation in interactive multimedia is interesting and easy to understand. But the languages used were still difficult to understand because they relate to foreign vocabulary. The average result of the questionnaire was 3.56 indicating they like this learning model. showed in Fig. 1 


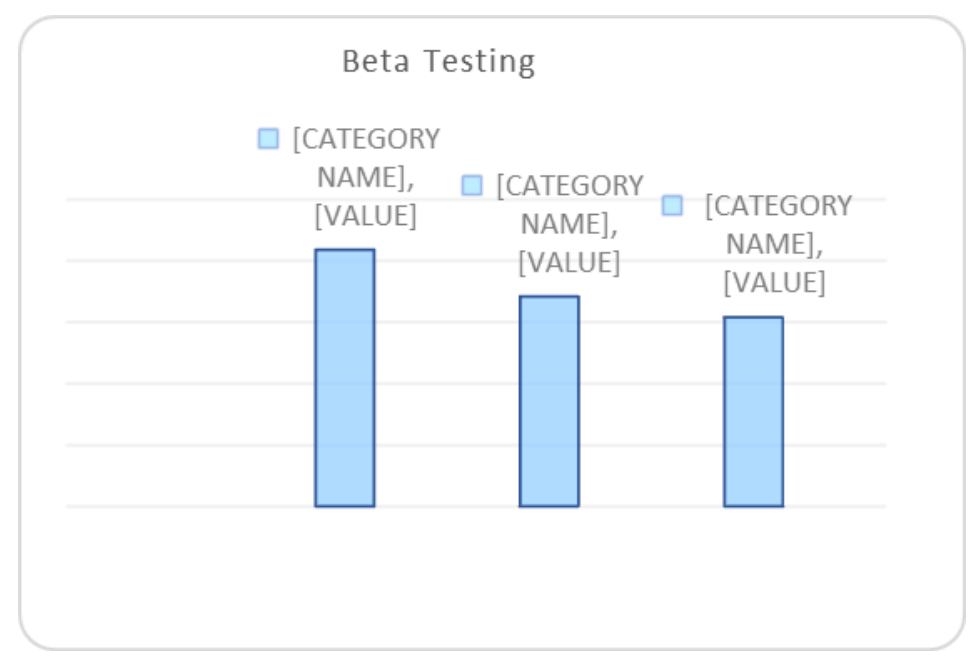

Fig. 2. Result of Beta testing

In the field test, the researcher distributed a questionnaire to see how deep the students' engagement level with this learning model. The questionnaire was developed from three main indicators in engagement learning, namely, cognitive, behavioural and emotional, distributed in 18 question items. The questionnaire distributed to examine how strongly students' engagement when they are learning using this learning model. The distribution of each indicator as shown in Table 2.

Table 2. Instrument grid of Students' engagement

\begin{tabular}{|c|c|c|}
\hline Indicators & Descriptor & Statements \\
\hline \multirow[t]{6}{*}{ Behavioral } & Concentration & 1. Are you resisting distraction when learning? \\
\hline & Seeking information & $\begin{array}{l}\text { 2. Are you seeking more information about your } \\
\text { material outside class hour? }\end{array}$ \\
\hline & & 3. Are you still open your online learning at home? \\
\hline & Questioning & 4. Do you like asking question in the classroom? \\
\hline & Answering & $\begin{array}{l}\text { 5. Do you like answering teacher and students question } \\
\text { in the classroom? }\end{array}$ \\
\hline & Completing utterances & $\begin{array}{l}\text { 6. Do you like completing teacher utterances when in } \\
\text { the classroom? }\end{array}$ \\
\hline \multirow[t]{6}{*}{ Cognitive } & Enhancing ideas & $\begin{array}{l}\text { 7. Do you make choices about how to approach your } \\
\text { work? }\end{array}$ \\
\hline & Verbalism thinking & 8. Are you make a note at the end of learning? \\
\hline & & 9. Do you rewrite your lesson? \\
\hline & Giving information & $\begin{array}{l}\text { 10. Are you giving information about the material to } \\
\text { your friends }\end{array}$ \\
\hline & Making Evaluation & 11. Do you make a conclusion about the lesson? \\
\hline & & 12. Are you giving comment in online discussion? \\
\hline \multirow[t]{2}{*}{ Emotional } & Self monitoring & $\begin{array}{l}\text { 13. Do you monitor the change of your own interest in } \\
\text { learning? }\end{array}$ \\
\hline & Happy learning & 14. Are you having fun with this learning method? \\
\hline
\end{tabular}




\begin{tabular}{ll}
\hline $\begin{array}{l}\text { Helping others to } \\
\text { understand the material }\end{array}$ & $\begin{array}{l}\text { 15. Are you taking a part in discussion? } \\
\text { 16. This learning method make you easier in learning? }\end{array}$ \\
\hline Pride & 17. Are you pride with this kind of method learning? \\
\hline Hope & $\begin{array}{l}\text { 18. Do you hope for other subject using this learning } \\
\text { method? }\end{array}$ \\
\hline
\end{tabular}

Data retrieval used Likert scale 5, with the results from the behavioural aspect got a score of 80.23 , which means students strongly engaged in this learning model. In the cognitive aspect, the score is 78.01 which means students' engagement to this learning model. The emotional aspect got a score of 79.65 also means students like this learning model. Overall this learning model combines between interactive multimedia with the module as shown in Table 3 .

Table 3. Result of students' engagement questionnaire

\begin{tabular}{l|ll} 
ASPECT & PERCENTAGE & CRITERION \\
\hline Behavioral & 80,23 & Strongly engaged \\
\hline Cognitive & 78,01 & Engaged \\
\hline Emotional & 79,65 & Engaged \\
\hline Average Score & 79,29 & Engaged \\
\hline
\end{tabular}

From the results of interviews, several things that make students like this learning model are they feel freer to repeat material, answer and ask questions using interactive multimedia. Another thing is that interactive multimedia makes students more easily understand the material because there are simulations and animations that make it clear, students can also repeat the material as needed. Another thing that is a weakness is the electricity and internet connection in Baturaja which is sometimes unstable.

\section{Conclusion}

This learning model is a combination of interactive multimedia and printed module. In the application of learning methods used are face to face meetings and independent learning. This learning model is declared valid and feasible to use after being validated by several experts, media experts, instructional design experts, and material experts. In the alpha test, the final results showed students like this learning model. The final result showed students engagement is more visible from the behavioural aspect. The results of this study can become a reference for lecturers and next research or developers in developing the next learning media.

Acknowledgment. I have great pleasure in acknowledging my gratitude to DRPM for acquisition funding to this research, thanks to my colleagues and fellow research at LPPM Baturaja University for general administrative support and thanks to Educational Technology Department at Baturaja University for helping and being cooperative team in doing this research. 


\section{References}

[1] D. H. Schunk, Learning Theories An Educational Perpective, Sixth Edit. Boston: Pearson, 2012.

[2] K. L. Huang, K. H. Chen, and C. H. Ho, "Enhancing Learning Outcomes Through New E-textbooks: A Desirable Combination of Presentation Methods and Concept Maps," Australas. J. Educ. Technol., vol. 30, no. 5, pp. 600-618, 2014.

[3] C. C. Chang, C. A. Warden, C. Liang, and G. Y. Lin, "Effects of Digital Game-Based Learning on Achievement, Flow and Overall Cognitive Load," Australas. J. Educ. Technol., vol. 34, no. 4, pp. 155-167, 2018.

[4] H. D. Surjono, "The Effects of Multimedia and Learning Style on Student Achievement in Online Electronics Course," Turkish Online J. Educ. Technol., vol. 14, no. 1, pp. 116-122, 2015.

[5] T. Vaughan, Multimedia: Making It Work, Eight Edit., vol. 63, no. 2. McGrow-Hill Companies, 2006.

[6] A. Suryansyah, B. Ambarita, and S. Purba, "Improving Teacher Skills in Using Interactive Multimedia Learning Media through Supervision with Lesson Study Approach at State Vocational High School 1 Nagan Raya," IOSR J. Res. Method Educ., vol. 7, no. 5, pp. 30-33, 2017.

[7] I. Deliyannis, Interactive Multimedia. Croatia: In. Tech Janeza Trdine, 2012.

[8] E. R. M. Richard Schwier, Interactive Multimedia Instruction. New Jersey: Educational Technolpgy Publications,Inc., 1993.

[9] T. N. M. Neo, "Classroom Innovation: Engaging Students in Interactive Multimedia Learning,” Campus-Wide Inf. Syst., vol. 21, no. issue 3, pp. 118-124, 2004.

[10] M. Csikszentmihalyi, "FLOW : The Psychology of Optimal Experience," New York: Global Learning Community, 2000.

[11] J. D. Willms, Student Engagement at School: A Sense of Belonging and Participation: Results from PISA 2000. OECD Organisation For Economic Co-Operation And Development, 2003.

[12] D. Shernoff, Optimal Learning Environments to Promote Student Engagement. New York: Springer, 2013.

[13] D. Mahatmya, B. J. Lohman, J. L. Matjasko, and A. F. Farb, "Engagement Across Developmental Periods," Handb. Res. Student Engagem., pp. 45-63, 2012.

[14] M. Gredler, Learning into Practice: Theory into Practice., Sixth edit. New Jersey: Merrill Pearson, 2009.

[15] J. Konert, "Interactive Multimedia Learning," Universität Darmstadt, Germany, Darmstadt, 2014.

[16] S. R. T. Stephen M. Alessi, Multimedia for Learning: Methods and Development. Massachusetts: Allyn \& Bacon, Incorporated, 2001. 